\title{
Evaluation of the possible direct effects of gonadotrophin-releasing hormone analogues on the monkey (Macaca mulatta) testis
}

\author{
D. R. Mann*, S. R. Adams $\dagger$, K. G. Gould $\ddagger$, T. E. Orr* and D. C. Collins $\S$ \\ * Department of Physiology, Morehouse School of Medicine, Atlanta, GA 30310, USA; †Centers for \\ Infectious Diseases, Public Health Service, U.S. Department of Health and Human Services, \\ Atlanta, GA 30333, USA; $\ddagger$ Yerkes Regional Primate Research Center, Atlanta, GA 30322, USA; \\ and \$Medical Research Services VA Medical Center and Departments of Medicine and \\ Biochemistry, Emory University School of Medicine, Atlanta, GA 30033, USA
}

Summary. In Exp. 1, the effect of treatment with a GnRH agonist on basal concentrations of serum testosterone and peak values of serum testosterone after administration of hCG was determined. One group of adult male monkeys was treated with a low dose $(5-10 \mu \mathrm{g} / \mathrm{day})$ and a second group with a high dose $(25 \mu \mathrm{g} / \mathrm{day})$ of a GnRH agonist for 44 weeks. Basal and peak testosterone concentrations were both significantly reduced by GnRH agonist treatment in all groups compared to untreated control animals, but the \% rise in serum testosterone above basal values in response to hCG administration was unchanged by agonist treatment.

In Exp. 2, the GnRH agonist (100 or $400 \mathrm{ng}$ ) or a GnRH antagonist $(4 \mu \mathrm{g})$ was infused into the testicular arteries of adult monkeys. The agonist did not alter testosterone concentrations in the testicular vein or testosterone and $\mathrm{LH}$ values in the femoral vein.

In Exp. 3, testicular interstitial cells from monkeys were incubated with three concentrations $\left(10^{-9}, 10^{-7}\right.$ and $\left.10^{-5} \mathrm{M}\right)$ of the $\mathrm{GnRH}$ agonist or a $\mathrm{GnRH}$ antagonist with and without hCG. After $24 \mathrm{~h}$, neither basal nor hCG-stimulated testosterone production was affected by the presence of the GnRH agonist or antagonist.

The results from all 3 experiments clearly suggest that GnRH agonist treatment does not directly alter steroid production by the monkey testis.

Keywords: GnRH; testes; LH; testosterone; rhesus monkey

\section{Introduction}

Chronic administration of gonadotrophin-releasing hormone $(\mathrm{GnRH})$ agonists causes azoospermia in monkeys and men (Akhtar et al., 1983a, b; Swerdloff et al., 1985; Mann et al., 1985, 1987). Simultaneous testosterone therapy to maintain libido and potency in men (Swerdloff et al., 1985; Bouchard et al., 1986) and ejaculatory response in monkeys (Mann et al., 1987) does not interfere with agonist-induced azoospermia. Administration of GnRH antagonists also suppresses spermatogenesis in primates although the doses of antagonist required for this effect are much greater than for agonists (Weinbauer et al., 1984; Akhtar et al., 1985). These developments suggest that GnRH analogues may be useful for male contraception.

The mechanism of the antifertility effects of $\mathrm{GnRH}$ analogues in primates remains undefined. GnRH agonists reduce the luteinizing hormone (LH) and testosterone response to GnRH (Akhtar et al., 1983b; Mann et al., 1985, 1987), presumably by down-regulating pituitary GnRH receptors, as reported for rats (Heber et al., 1982). GnRH antagonists bind with high affinity to GnRH 
receptors in the pituitary, preventing binding by $\mathrm{GnRH}$ (Clayton et al., 1982). In the rat, these analogues also directly inhibit gonadal steroidogenesis (Hsueh \& Erickson, 1979; Clayton et al., 1980; Hsueh et al., 1981; Sharpe \& Cooper, 1982a, b, 1987; Sharpe, 1982; Spona et al., 1985). However, most evidence does not support a gonadal site of action of these analogues in primates. GnRH agonist treatment does not abolish the testicular response to LH or hCG in primates (Mann et al., 1984; Schaison et al., 1984; Heber et al., 1984; Evans et al., 1984), and GnRH receptors were not demonstrated on the primate gonad (Asch et al., 1981; Clayton \& Huhtaniemi, 1982).

Evidence for a direct effect of GnRH or GnRH-like peptides on the primate gonad is supported by findings that the seminiferous tubules of the stump-tailed macaque contain low-affinity GnRH-binding sites and GnRH-like biological acivity, and human seminal plasma has GnRH-like immunoactivity (Sharpe et al., 1981; Swerdloff et al., 1984). In addition, the presence of a GnRH agonist inhibited progesterone secretion from cultured human granulosa cells (Tureck et al., 1982). Progesterone secretion was normal with simultaneous incubation with a GnRH antagonist (Tureck et al., 1982). These results clearly indicate that the question about a direct effect of GnRH agonists on the primate gonad has not been resolved.

In this study, we tested the hypothesis that there is a direct effect of GnRH analogues on the testis of the rhesus monkey. We examined the effect of: (1) chronic GnRH agonist administration (44 weeks) on the testicular response to a low dose of hCG, (2) acute infusion of a GnRH agonist or antagonist into the testicular artery on testosterone release into the testicular vein in adult monkeys and (3) in-vitro incubation of monkey testicular interstitial cells with a GnRH agonist or antagonist on basal and hCG-stimulated testosterone production.

\section{Materials and Methods}

The 23 adult male rhesus monkeys (Macaca mulatta) used in this study were housed under a 12-h light:12-h dark lighting schedule (lights on: $06: 00 \mathrm{~h}$ ) at $20-23^{\circ} \mathrm{C}$.

Experiment 1: effect of chronic GnRH agonist administration on the response to $h C G$. Ten monkeys were allocated randomly to two groups. Group 1 animals were treated continuously with a $\mathrm{GnRH}$ agonist $\left(\mathrm{D}-\mathrm{Trp}^{6} \cdot N\right.$-alpha-MeLeu $^{7}$-desGly ${ }^{10}$-Pro ${ }^{9}$-NHEt-GnRH; Wyeth Laboratories, Philadelphia, PA), $5 \mu \mathrm{g} /$ day for 24 weeks followed by a dose of $10 \mu \mathrm{g} /$ day of the same agonist for 20 weeks, using an osmotic minipump as previously described (Mann et al., 1985, 1987). The dose of agonist was doubled from 5 to $10 \mu \mathrm{g} /$ day after 24 weeks because the $5 \mu \mathrm{g} /$ day dose was not effective in reducing sperm counts (Mann et al., 1987). Group 2 monkeys received $25 \mu \mathrm{g}$ agonist/day for 44 weeks. Pumps were replaced at 4-week intervals. All animals were injected i.v. with 50 i.u. hCG during the control (pretreatment) period and at the end of 44 weeks of agonist administration. Blood samples were taken $15 \mathrm{~min}$ before and at $0,30,60$ and $120 \mathrm{~min}$ after hCG administration for determination of testosterone by radioimmunoassay.

Experiment 2: influence of acute infusion of a GnRH agonist or antagonist into the testicular artery on serum testosterone concentrations in testicular vein. Eighteen adult male monkeys were used with each animal serving as its own control. Animals were anaesthetized with $30 \mathrm{mg}$ ketamine $\mathrm{HCl} / \mathrm{kg}$ and prepared for abdominal surgery under sterile conditions. A midline incision was made in the abdominal region and the inguinal canal identified on one side of the animal. The GnRH agonist (100 or $400 \mathrm{ng}$ ), a GnRH antagonist (4 $\mu$; Ac-D-pClPhe-D-Trp-Ser-Tyr-D-ArgLeu-Arg-Pro-D-Ala- $\mathrm{NH}_{2} \cdot \mathrm{CH}_{3} \mathrm{COOH}$; Organon, Oss, The Netherlands) or saline $(0 \cdot 154 \mathrm{M}-\mathrm{NaCl})$ was infused into the testicular artery (proximal to its involvement with the pampiniform plexus) over a 1-min period, and blood samples were taken from the testicular $(0.5 \mathrm{ml})$ and femoral veins $(4 \mathrm{ml})$ before and at $15,30,60$ and $120 \mathrm{~min}$ after administration of the agonist for testosterone and LH determination. Analgesics were administered during the immediate post-surgical period. After a 2-3-month recovery period, animals were subjected to the identical procedure on the other testis.

Experiment 3: effect of GnRH agonist or antagonist treatment on testosterone production from monkey testicular interstitial cells. Testicular interstitial cells were prepared from 2 sexually mature male monkeys ( 3.5 and 12 years old). The testes were decapsulated and the remaining tissue was minced into small pieces. The tissue was then incubated in Medium 199 (pH 7.4; GIBCO, Grand Island, NY, USA) containing $1.0 \mathrm{mg}$ collagenase/ml and $100 \mathrm{i}$.u. penicillinstreptomycin $/ \mathrm{ml}$ in a shaking water bath at $34^{\circ} \mathrm{C}$ for $45 \mathrm{~min}$ under an atmosphere of $5 \% \mathrm{CO}_{2}: 95 \% \mathrm{O}_{2}$. The cell suspension was then filtered through nylon (Nitex, mesh no. HD3-100, Tetko Inc., Elmsforce, NY, USA) and washed 3 times with Medium 199 without collagenase followed each time with centrifugation ( $400 \mathrm{~g}$ for $5 \mathrm{~min}$ at $4^{\circ} \mathrm{C}$ ). Cells were counted with a haemocytometer and viability was assessed with trypan blue. Cells were rediluted to $10^{7}$ cells per $\mathrm{ml}$ in Medium 199 containing $0 \cdot 1 \mathrm{~mm}$-isobutyl-1-methylxanthine. 
In Exp. 3A, cells $\left(10^{6}\right)$ were incubated with $0,10^{-9}, 10^{-7}$ or $10^{-5} \mathrm{M}$ agonist in the absence or presence of hCG $(50$, 250 or $1000 \mu$ i.u.) for $24 \mathrm{~h}$ at $34^{\circ} \mathrm{C}$ under an atmosphere of $5 \% \mathrm{CO}_{2}: 95 \% \mathrm{O}_{2}$ in a shaking water bath. In Exp. 3B, the agonist was replaced with $10^{-9}, 10^{-7}$ and $10^{-5} \mathrm{M}$ antagonist in the presence or absence of hCG. Viability of cells was reassessed at the end of the incubation period. Cells were removed by centrifugation and testosterone concentration was determined in the incubation medium.

Assays. Serum concentrations of LH were measured using the mouse interstitial cell bioassay (Van Damme et al., 1974). A rhesus monkey pituitary gonadotrophin standard (LER 1909-2) provided by the National Institutes of Diabetes and Diseases of the Kidney was used as the reference preparation. The intra- and interassay coefficients of variation were $11.2 \%$ and $14.7 \%$ respectively. The usable range of the LH bioassay standard curve was from 0.2 to $10 \mu \mathrm{g} / \mathrm{ml}$. Serum testosterone concentrations were measured by radioimmunoassay as described in detail previously (Perachio et al., 1977). The intra- and interassay coefficients of variation were $4.8 \%$ and $6.7 \%$ respectively. The usable portion of the testosterone standard curve was from 2 to $50 \mathrm{nmol} / 1$.

Statistical analysis. Data from Exps 1 and 2 were evaluated by a one-way analysis of variance (agonist treatment) with repeated measures (blood samples over time) followed by the least significant difference test for multiple comparisons. In Exp. 3, data were evaluated by a two-way analysis of variance (agonist or antagonist treatment in the presence or absence of hCG).

\section{Results}

\section{Experiment 1: effect of chronic GnRH agonist administration on the response to $h C G$}

Basal serum concentrations of testosterone were reduced in adult male monkeys in Group 1 and 2 compared to basal values during the control (pretreatment) period (Fig. 1). The peak serum testosterone concentration after an i.v. bolus of hCG was $<40 \%$ of the control peak in Group 1 $(P<0.001)$ and $<30 \%$ in Group $2(P<0.001)$ (Fig. 1). However, when the lower basal values of testosterone in Groups 1 and 2 after agonist treatment were considered, the overall \% increase of testosterone in response to hCG after agonist treatment in Groups 1 and $2(666 \% \pm 117$ and $892 \% \pm 436)$ did not differ from the control response $(652 \% \pm 97)$.

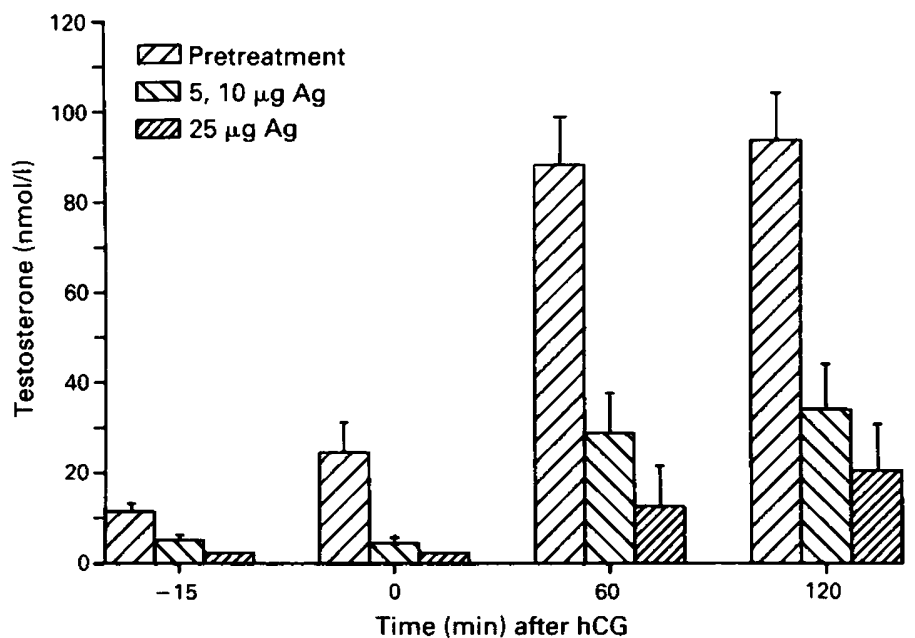

Fig. 1. Serum testosterone concentrations before and after hCG administration in adult male monkeys. $\mathrm{Ag}=$ agonist. Group $1(\mathrm{~N}=5)$ : $\mathrm{GnRH}$ agonist, $5 \mu \mathrm{g} /$ day for 24 weeks and then $10 \mu \mathrm{g} /$ day for 20 weeks. Group $2(\mathrm{~N}=5)$ : $\mathrm{GnRH}$ agonist, $25 \mu \mathrm{g} /$ day for 44 weeks. Animals in Groups 1 and 2 had lower basal values $(P<0.05)$ and reduced peak values of serum testosterone after hCG $(P<0.001)$ than during the pretreatment period. 
Experiment 2: influence of acute infusion of GnRH agonist or antagonist into the testicular artery on testosterone concentrations in the testicular and femoral veins

Infusion of 100 or $400 \mathrm{ng} \mathrm{GnRH}$ agonist into the testicular artery failed to change testosterone concentrations in the testicular vein or systemic circulation over the next $2 \mathrm{~h}$ (Table 1). The infusion of $4 \mu \mathrm{g} \mathrm{GnRH}$ antagonist also failed to influence testicular secretion of testosterone into the testicular vein (Table 1).

Table 1. Effect of infusion (over $1 \mathrm{~min}$ ) of 100 or $400 \mathrm{ng} \mathrm{GnRH}$ agonist or $4 \mu \mathrm{g}$ antagonist into the testicular artery on testosterone concentrations in the testicular vein and on LH and testosterone concentrations ( \pm s.e.m.) in the femoral vein in adult monkeys

\begin{tabular}{|c|c|c|c|c|c|c|}
\hline & \multicolumn{6}{|c|}{ Time (min) after agonist or saline infusion } \\
\hline & -15 & 0 & 15 & 30 & 60 & 120 \\
\hline & \multicolumn{6}{|c|}{ Testicular vein testosterone $(\mathrm{nmol} / \mathrm{l})$} \\
\hline Control & $\begin{array}{r}198 \\
\pm 71\end{array}$ & $\begin{array}{r}189 \\
\pm 52\end{array}$ & $\begin{array}{r}156 \\
\pm 42\end{array}$ & $\begin{array}{r}170 \\
\pm 38\end{array}$ & $\begin{array}{r}125 \\
\pm 34\end{array}$ & $\begin{array}{r}90 \\
\pm 20\end{array}$ \\
\hline \multicolumn{7}{|l|}{ Agonist } \\
\hline \multirow[t]{2}{*}{$100 \mathrm{ng}$} & 183 & 237 & 157 & 141 & 253 & 130 \\
\hline & \pm 87 & \pm 116 & \pm 74 & \pm 64 & \pm 180 & \pm 44 \\
\hline \multirow[t]{2}{*}{$400 \mathrm{ng}$} & 135 & 127 & 234 & 271 & 304 & 122 \\
\hline & \pm 41 & \pm 40 & \pm 71 & \pm 70 & \pm 99 & \pm 29 \\
\hline \multicolumn{7}{|l|}{ Antagonist } \\
\hline \multirow[t]{3}{*}{$4 \mu \mathrm{g}$} & 193 & 202 & 155 & 194 & 186 & 135 \\
\hline & & & \pm 33 & & & \\
\hline & \multicolumn{6}{|c|}{ Femoral vein testosterone (nmol/1) } \\
\hline \multirow[t]{2}{*}{ Control } & 15 & 21 & 17 & 19 & 16 & 12 \\
\hline & \pm 5 & \pm 7 & \pm 6 & \pm 6 & \pm 5 & \pm 4 \\
\hline \multicolumn{7}{|l|}{ Agonist } \\
\hline \multirow[t]{2}{*}{$100 \mathrm{ng}$} & 24 & 18 & 15 & 14 & 15 & 11 \\
\hline & \pm 9 & \pm 5 & \pm 3 & \pm 3 & \pm 5 & \pm 2 \\
\hline \multirow[t]{2}{*}{$400 \mathrm{ng}$} & 14 & 15 & 18 & 17 & 17 & 16 \\
\hline & \pm 4 & \pm 4 & \pm 2 & \pm 3 & \pm 3 & \pm 3 \\
\hline \multicolumn{7}{|l|}{ Antagonist } \\
\hline \multirow{3}{*}{$4 \mu \mathrm{g}$} & 11 & 12 & 13 & 14 & 14 & 11 \\
\hline & \pm 2 & \pm 2 & \pm 2 & \pm 2 & \pm 2 & \pm 1 \\
\hline & \multicolumn{6}{|c|}{ Femoral vein $\mathrm{LH}(\mu \mathrm{g} / \mathrm{ml})$} \\
\hline Control & $3 \cdot 2$ & $3 \cdot 3$ & 2.7 & 2.7 & 1.9 & $1 \cdot 2$ \\
\hline & \pm 0.5 & $\pm 0 \cdot 5$ & $\pm 0 \cdot 4$ & \pm 0.5 & $\pm 0 \cdot 3$ & $\pm 0 \cdot 2$ \\
\hline \multicolumn{7}{|l|}{ Agonist } \\
\hline \multirow[t]{2}{*}{$100 \mathrm{ng}$} & $3 \cdot 5$ & $3 \cdot 6$ & 3.9 & $4 \cdot 1$ & $3 \cdot 0$ & 1.8 \\
\hline & $\pm 1 \cdot 1$ & $\pm 1 \cdot 2$ & $\pm 1 \cdot 2$ & $\pm 1 \cdot 4$ & \pm 0.9 & \pm 0.5 \\
\hline \multirow[t]{2}{*}{$400 \mathrm{ng}$} & $4 \cdot 4$ & $4 \cdot 4$ & 6.8 & $6 \cdot 2$ & $6 \cdot 3$ & 2.9 \\
\hline & \pm 0.8 & $\pm 0 \cdot 6$ & \pm 1.6 & \pm 1.9 & $\pm 1 \cdot 7$ & \pm 0.7 \\
\hline \multicolumn{7}{|l|}{ Antagonist } \\
\hline $4 \mu \mathrm{g}$ & 3.0 & $3 \cdot 3$ & $3 \cdot 5$ & $2 \cdot 5$ & $2 \cdot 1$ & $1 \cdot 6$ \\
\hline & \pm 0.8 & $\pm 0 \cdot 9$ & $\pm 1 \cdot 3$ & $\pm 0 \cdot 8$ & \pm 0.7 & \pm 0.5 \\
\hline
\end{tabular}

Values are mean \pm s.e.m.; $\mathrm{N}=6$ for each $\mathrm{GnRH}$ analogue treated group and each animal served as its own control.

Experiment 3: effect of a GnRH agonist or antagonist on testosterone production from monkey testicular interstitial cells in vitro

As shown in Table 2, incubation of testicular interstitial cells with $10^{-9}, 10^{-7}$ or $10^{-5} \mathrm{M}-\mathrm{GnRH}$ agonist or antagonist failed to alter the amount of testosterone in the incubation medium after $24 \mathrm{~h}$; 
testosterone production ranged from 4.4 and $4.7 \mathrm{pmol}$ in Exp. 3A and 1.0 to $1.2 \mathrm{pmol}$ in Exp. 3B. Untreated interstitial cells showed a dose-related increase $(P<0.001)$ in testosterone production

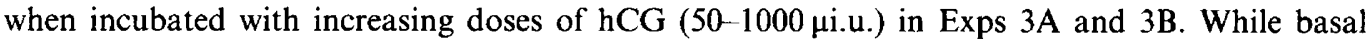
testosterone production was lower in Exp. 3B than in Exp. 3A, the overall response of cells (based on the \% increase over basal values) to hCG did not differ between the two experiments ( $743 \%$ and $745 \%$ ). The response of these cells to hCG was not affected by the presence of the GnRH agonist or antagonist in the incubation medium.

Table 2. Effect of a GnRH agonist and antagonist on testosterone production ( $\mathrm{pmol} / 10^{6}$ cells $/ 24 \mathrm{~h}$ ) by isolated testicular interstitial cells from male monkeys

\begin{tabular}{|c|c|c|c|c|c|}
\hline \multirow[b]{2}{*}{ Exp. } & \multicolumn{4}{|c|}{ hCG dose ( $\mu$ i.u.) } & \multirow[b]{2}{*}{1000} \\
\hline & Treatment & 0 & 50 & 250 & \\
\hline \multirow[t]{8}{*}{$3 \mathrm{~A}$} & Control & $\begin{array}{r}4.7 \\
+0.5\end{array}$ & $\begin{array}{r}7.4 \\
+1.0\end{array}$ & $\begin{array}{r}18.9 \\
+1.0\end{array}$ & $\begin{array}{r}30.0 \\
+1.8\end{array}$ \\
\hline & Agonist & & & & \\
\hline & $10^{-9} \mathrm{M}$ & $4 \cdot 6$ & $7 \cdot 0$ & $19 \cdot 4$ & $34 \cdot 2$ \\
\hline & & \pm 0.4 & $\pm 0 \cdot 5$ & $\pm 0 \cdot 7$ & $\pm 2 \cdot 3$ \\
\hline & $10^{-7} \mathrm{M}$ & $4 \cdot 5$ & $7 \cdot 5$ & $24 \cdot 5$ & $32 \cdot 9$ \\
\hline & & \pm 0.4 & $\pm 0 \cdot 5$ & $\pm 2 \cdot 0$ & 1.4 \\
\hline & $10^{-5} \mathrm{M}$ & $4 \cdot 4$ & $7 \cdot 5$ & $21 \cdot 0$ & $33 \cdot 6$ \\
\hline & & \pm 0.4 & \pm 0.5 & $\pm 2 \cdot 8$ & $\pm 2 \cdot 0$ \\
\hline \multirow[t]{9}{*}{$3 \mathrm{~B}$} & Control & $1 \cdot 1$ & $2 \cdot 0$ & $6 \cdot 0$ & $8 \cdot 2$ \\
\hline & & $\pm 0 \cdot 1$ & $\pm 0 \cdot 1$ & \pm 0.4 & \pm 0.5 \\
\hline & Antagonist & & & & \\
\hline & $10^{-9} \mathrm{M}$ & $1 \cdot 0$ & 1.7 & 3.9 & $9 \cdot 6$ \\
\hline & & $\pm 0 \cdot 1$ & $\pm 0 \cdot 2$ & $\pm 0 \cdot 2$ & $\pm 0 \cdot 4$ \\
\hline & $10^{-7} \mathrm{M}$ & $1 \cdot 2$ & 1.6 & $4 \cdot 5$ & $7 \cdot 4$ \\
\hline & & $\pm 0 \cdot 1$ & $\pm 0 \cdot 1$ & $\pm 0 \cdot 3$ & \pm 0.4 \\
\hline & $10^{-5} \mathrm{M}$ & 1.0 & 1.4 & $4 \cdot 7$ & $8 \cdot 7$ \\
\hline & & $\pm 0 \cdot 1$ & $\pm 0 \cdot 1$ & $\pm 0 \cdot 2$ & $\pm 0 \cdot 7$ \\
\hline
\end{tabular}

Values are mean \pm s.e.m. of at least 5 incubates.

\section{Discussion}

It has been clearly established that GnRH analogues have direct effects on testicular function in the rat. In hypophysectomized rats, GnRH agonists inhibited steroidogenesis, reduced the responsiveness to LH, and blocked FSH induction of LH receptors on Leydig cells (Bambino et al., 1980; Hsueh et al., 1981). In-vitro incubation of testicular interstitial or purified Leydig cells with GnRH agonist had a biphasic effect on testosterone production. Acutely, GnRH agonists increased testosterone production. However, the effect on testicular steroidogenesis was inhibitory in long-term incubations (24-27 h) (Hsueh et al., 1981; Sharpe \& Cooper, 1982a). Binding sites for GnRH were reported on rat Leydig cells (Hsueh \& Erickson, 1979; Clayton et al., 1980), and GnRH-like factors have been demonstrated in the rat testis (Sharpe et al., 1981; Swerdloff et al., 1984). These data support the hypothesis that there is a GnRH-like gonadal peptide involved in modulating testicular steroidogenesis in the rat testis.

The results reported here do not demonstrate a direct effect of a GnRH agonist or antagonist on testicular steroidogenesis in the primate testis. Chronic GnRH agonist treatment for 44 weeks inhibited spermatogenesis and reduced basal concentrations of testosterone (Mann et al., 1987), 
but failed to alter the testicular testosterone response (based on the $\%$ increase of serum testosterone after hCG to the basal testosterone value) of these animals to a low dose of hCG. However, absolute peak concentrations of testosterone after hCG administration were lower in agonisttreated animals than they were during the control period.

Infusion of 100 or $400 \mathrm{ng} \mathrm{GnRH}$ agonist or $4 \mu \mathrm{g}$ antagonist directly into the testicular artery did not significantly alter testosterone concentrations in the testicular vein over the next $2 \mathrm{~h}$. However, serum LH concentrations in animals treated with $400 \mathrm{ng}$ agonist were slightly elevated 15 and $30 \mathrm{~min}$ after agonist administration, suggesting that this dose of agonist approaches levels that would stimulate pituitary LH secretion, and therefore, testicular testosterone secretion indirectly.

Finally, in-vitro incubation of testicular interstitial cells from sexually mature male monkeys with the GnRH agonist or antagonist $\left(10^{-9}\right.$ to $\left.10^{-5} \mathrm{M}\right)$ for $24 \mathrm{~h}$ did not affect either testosterone production or the testosterone response to hCG stimulation. These results do not rule out the possibility that shorter or longer term incubations of the cells with the analogues would have influenced steroidogenesis. However, GnRH agonist treatment of male monkeys for 44 weeks did not alter the testicular testosterone response to a low dose of hCG in vivo. Therefore, the in-vivo and in-vitro evidence from the present study does not support the hypothesis that GnRH analogues directly alter testicular steroidogenesis.

The results reported here provide the first direct evidence in vivo and in vitro that $\mathrm{GnRH}$ analogues do not directly alter testicular steroidogenesis in primates. These data are in agreement with a recent report that showed chronic GnRH agonist treatment for 1 year of men with prostatic cancer resulted in an inhibition of the production of $\Delta^{4}$ and $\Delta^{5}$ steroids in the testis. This inhibition was overcome by treatment with exogenous hCG (Rajfer et al., 1987). Thus, most evidence does not support the hypothesis that the testis is a site for the inhibitory effects of GnRH agonists on gonadal function. Nevertheless, there is a need to be cautious. Data continue to accumulate suggesting the presence of a GnRH-like protein in the primate gonad (human ovary) (Aten et al., 1987). Moreover, while monkey testicular interstitial cells incubated for $24 \mathrm{~h}$ with a GnRH agonist or antagonist failed to show any change in testosterone production in the present study, it is possible that more chronic treatment with the analogues would have altered either basal testosterone secretion or the response of these cells to hCG.

We thank Wyeth Laboratories and Organon for the GnRH agonist and antagonist used in this study; the NIADDK for providing the rhesus monkey pituitary reference preparation (LER-1909-2); Dr Gordon Niswender for the testosterone antiserum; and Ms. Toni Duffey, Janice Tittle, Robin King and Mr Thomas Buckner for technical assistance. Supported by AID grant DAN-5053-G-SS5018-00, NIH grants RR-08006 and RR-00165 and Veterans Administration project 1517-001.

\section{References}

Akhtar, F.B., Marshall, G.R. \& Nieschlag, E. (1983a) Testosterone supplementation attenuates the antifertility effects of an LHRH agonist in male rhesus monkeys. Int. J. Androl. 6, 461-468.

Akhtar, F.B., Marshall, G.R., Wickings, E.J. \& Nieschlag, E. (1983b) Reversible induction of azoospermia in rhesus monkeys by constant infusion of a gonadotrophin-releasing hormone agonist using osmotic minipumps. J. clin. Endocr. Metab. 56, $534-540$.

Akhtar, F.B., Weinbauer, G.F. \& Nieschlag, E. (1985) Acute and chronic effects of a gonadotrophinreleasing hormone antagonist on pituitary and testicular function in monkeys. $J$. Endocr. 104, 345-354.

Asch, R.H., Sickle, M.V., Rettori, V., Balmaceda, J.P., Eddy, C.A., Coy, D.H. \& Schally, A.V. (1981)
Absence of LHRH binding sites in corpora lutea from rhesus monkeys (Macaca mulatia). J. clin. Endocr. Metab. 53, 21 5-217.

Aten, R.F., Ireland, J.J., Weems, C.W. \& Behrman, H.R. (1987) Presence of gonadotrophin-releasing hormonelike proteins in bovine and ovine ovaries. Endocrinology 120, 1727-1733.

Bambino, T.H., Schreiber, J.R. \& Hsueh, A.J.W. (1980) Gonadotropin-releasing hormone and its agonist inhibit testicular luteinizing hormone receptor and steroidogenesis in immature and adult hypophysectomized rats. Endocrinology 107, 908-917.

Bouchard, P., Blondet, C., Brailly, S. \& Schaison, G. (1984) Role of testosterone in human spermatogenesis-effect of GnRH agonists. Annls Endocrinol. 47, 286. 
Clayton, R.N. \& Huhtaniemi, I.T. (1982) Absence of gonadotropin-releasing hormone receptors in human gonadal tissue. Nature, Lond. 299, 56-59.

Clayton, R.N., Katikineni, M., Chan, V., Dufau, M.L. \& Catt, K.J. (1980) Direct inhibition of testicular function by gonadotropin-releasing hormone: mediation by specific gonadotropin-releasing hormone receptors in interstitial cells. Proc. natl. Acad. Sci. U.S.A. 77, 4459-4463.

Clayton, R.N., Channabasaviah, K., Stewart, J.M. \& Catt, K.J. (1982) Hypothalamic regulation of pituitary gonadotropin-releasing hormone receptors: effects of hypothalamic lesions and a gonadotropinreleasing hormone antagonist. Endocrinology 110, $1108-1115$.

Evans, R.M., Doelle, G.C., Lindner, J., Bradley, V. \& Rabin, D. (1984) A luteinizing hormone-releasing hormone agonist decreases biological activity and modifies chromatographic behavior of luteinizing hormone in man. J. Clin. Invest. 73, 262-266.

Heber, D., Dodson, R., Stoskopf, C., Peterson, M. \& Swerdloff, R.S. (1982) Pituitary desensitization and the regulation of pituitary gonadotropin-releasing hormone (GnRH) receptors following chronic administration of a superactive $\mathrm{GnRH}$ analog and testosterone. Life Sci. 30, 2301-2308.

Heber, D., Bhasin, S., Steiner, B. \& Swerdloff, R.S. (1984) The stimulatory and down-regulatory effects of a gonadotrophin-releasing hormone agonist in man. J. clin. Endocr. Metab. 58, 1084-1088.

Hsueh, A.J.W. \& Erickson, G.F. (1979) Extra-pituitary inhibition of testicular function by luteinising hormone releasing hormone. Nature, Lond. 281, 66-67.

Hsueh, A.J.W., Schreiber, J.R. \& Erickson, G.F. (1981) Inhibitory effect of gonadotropin releasing hormone upon cultured testicular cells. Molec. cell. Endocrinol. 21, $43-49$.

Mann, D.R., Gould, K.G. \& Collins, D.C. (1984) Influence of continuous gonadotropin-releasing hormone $(\mathrm{GnRH})$ agonist treatment on luteinizing hormone and testosterone secretion, the response to $\mathrm{GnRH}$, and the testicular response to human chorionic gonadotropin in male rhesus monkeys. $J$. clin. Endocr. Metab. 58, 262-267.

Mann, D.R., Smith, M.M., Gould, K.G. \& Collins, D.C. (1985) Effect of a gonadotropin-releasing hormone agonist on luteinizing hormone and testosterone secretion and testicular histology in male rhesus monkeys. Fert. Steril. 43, 115-121.

Mann, D.R., Gould, K.G., Smith, M.M., Duffey, T. \& Collins, D.C. (1987) Influence of simultaneous gonadotropin releasing hormone agonist and testosterone treatment on spermatogenesis and potential fertilizing capacity in male monkeys. $J$. clin. Endocr. Metab. 65, 1215-1224.

Perachio, A.A., Alexander, M., Marr, L. \& Collins, D.C.
(1977) Diurnal variations of serum testosterone levels in intact and gonadectomized male and female rhesus monkeys. Steroids 29, 21-33.

Rajfer, J., Sikka, S.C. \& Swerdloff, R.S. (1987) Lack of a direct effect of gonadotropin hormone-releasing hormone agonist on human testicular steroidogenesis. J. clin. Endocr. Metab. 64, 62-67.

Schaison, G., Brailly, S., Vuagnat, P., Bouchard, P. \& Milgrom, E. (1984) Absence of a direct inhibitory effect of the gonadotropin-releasing hormone ( $\mathrm{GnRH})$ agonist D-ser(TBU) ${ }^{6}$, des-gly- $\mathrm{NH}_{2}{ }^{10} \mathrm{GnRH}$ ethylamide (Buserelin) on testicular steroidogenesis in men. J. clin. Endocr. Metab. 58, 885-888.

Sharpe, R.M. (1982) Cellular aspects of the inhibitory actions of LH-RH on the ovary and testis. J. Reprod. Fert. 64, 517-527.

Sharpe, R.M. \& Cooper, I. (1982a) The mode of action of LHRH agonists on the rat Leydig cell. Molec. cell. Endocrinol. 27, 199-211.

Sharpe, R.M. \& Cooper, I. (1982b) Stimulatory effect of LHRH and its agonists on Leydig cell steroidogenesis in vitro. Molec. cell. Endocrinol. 26, 141-150.

Sharpe, R.M. \& Cooper, I. (1987) Comparison of the effects on purified Leydig cells of four hormones (oxytocin, vasopressin, opiates and LHRH) with suggested paracrine roles in the testis. J. Endocr. 113, 89-96.

Sharpe, R.M., Fraser, H.M., Cooper, I. \& Rommerts, F.F.G. (1981) Sertoli-Leydig cell communication via an LHRH-like factor. Nature, Lond. 290, 785-787.

Spona, J., Coy, D.H., Zatlasch, E. \& Wakolbinger, Ch. (1985) LH-RH antagonist inhibits gonadal steroid secretion in vitro. Peptides 6, 379-382.

Swerdloff, R.S., Bhasin, S. \& Sokol, R. (1984) GnRH-like factors in the rat testis and human seminal plasma. Ann. N.Y. Acad. Sci. 438, 382-389.

Swerdloff, R.S., Steiner, B.S. \& Bhasin, S. (1985) Gonadotropin releasing hormone $(\mathrm{GnRH})$ agonists in male contraception. Med. Biol. 63, 218-224.

Tureck, R.W., Mastroianni, L., Jr, Blasco, L. \& Strauss J.F. III (1982) Inhibition of human granulosa cell progesterone secretion by a gonadotropin-releasing hormone agonist. J. clin. Endocr. Metab. 54, 1078-1080.

Van Damme M.-P., Robertson, D.M. \& Diczfalusy, E. (1974) An improved in vitro bioassay method for measuring luteinizing hormone $(\mathrm{LH})$ activity using mouse Leydig cell preparations. Acta endocr., Copenh. 77, 655-671.

Weinbauer, G.F., Surmann, F.J., Akhtar, F.B., Shah, G.V., Vickery, B.H. \& Nieschlag, E. (1984) Reversible inhibition of testicular function by a gonadotropin hormone-releasing antagonist in monkeys (Macaca fascicularis). Fert. Steril. 42, 906-914.

Received 6 April 1988 